\title{
ЛОНДОНСЬКА ГАЗЕТА «УКРАЇНСЬКА ДУМКА» (1947-2017): СТАНОВЛЕННЯ, РЕДАКЦЙНА ПОЛІТИКА, СПРОБИ САМОІДЕНТИФІКАЦІЇ ТА ВИЖИВАННЯ В ЧУЖОМОВНОМУ ОТОЧЕННІ
}

\author{
Микола Тимошик \\ Київський національний університет культури і мистецттв, \\ вул. С. Коновальия, 36, 01133, Київ, Украӥна \\ e-mail: nkin@ukr.net \\ https://orcid.org/0000-0002-7011-3022
}

Уперше предметом дослідження стала одна з провідних газет західної української діаспори - лондонська «Українська Думка». Заснована 1947 року, припинила своє існування 2017 року. Повної підшивки цієї газети немає в жодній книгозбірні України, вона досі не оцифрована, редакція не мала сайту. 3 огляду на це автор проводив дослідження цієї газети в бібліотеці-архіві Союзу Українців у Великої Британії (СУБ) у Лондоні.

Об’єктом обсервації стали також пов’язані з діяльністю цієї редакції архівні документи та матеріали Української Видавничої Спілки в Лондоні та Британської Національної Бібліотеки (British Library).

3'ясовано особливості становлення часопису та специфіку редакційної політики. Аналіз підшивки дав змогу уточнити дату заснування часопису, яка в деяких інтернетних матеріалах подається неточно. Попередник «Української Думки» бюлетень «Наш Клич», який пізніше перебрав до своїх рук СУБ і зробив своїм органом, з'явився у світ 18 листопада 1945 року. «Українська Думка» - 9 лютого 1947 року. Саме цією датою позначалося перше число нової газети. Тому зараховувати «Українській Думці» час її постання від 1945 року недоцільно.

Корекція редакційної політики часопису була частою, як і зміна головних редакторів. Це пояснюється суперечностями між метою редакції стати трибуною всього українського елементу та спробами засновника дотримуватися статутних вимог організації.

Ключові слова: газета «Українська Думка», газета «Наш Клич», українська діаспора, Союз Українців у Великій Британії, редакційна політика.

\section{Постановка проблеми}

Українське журналістикознавство у великому боргу перед творцями «періодичних літописців сучасності». За майже три десятиліття української незалежності історія національної журналістики так і не написана. І це за умов, що журналістика викладається в понад півсотні українських університетів, де створені відповідні кафедри. За взірець тут є хіба що дослідницький центр періодики Львівської націо-

(C) Тимошик М., 2020 
нальної бібліотеки ім. В. Стефаника з його безцінними випусками «Української журналістики в іменах», що стали основою створення кількатомового словника-довідника, та низкою монографій.

Особливо знехтуваною є історія преси української діаспори. Проблема ускладнюється тим, що переважна більшість цих періодичних видань не була оцифрованою. За умов зменшення матеріальних спроможностей наших земляків за океаном ця важлива робота навряд чи в ближчій перспективі буде зроблена.

Прикладів тут можна навести багато. От хоча б оцих два.

На очах гине значна частина національного духовного спадку. Йдеться передусім про безцінну колекцію рукописів, стародруків і підшивок давньої періодики у французькому Сарселі - потужному осередкові українського духу, де в непевні післявоєнні роки Володимир Кубійович зібрав десяток відчайдухів з української інтелектуальної еліти та створив знамениту десятитомну «Енциклопедію українознавства». Упродовж тривалого часу Українська держава так і не прийняла прийнятного рішення щодо долі цієї безцінної колекції і цього сакрального для української історії будинку.

Із зміною статусу Українського вільного університету у Мюнхені та припиненням його фінансування центральним німецьким урядом з новою гостротою постає питання про долю колекції періодики та рукописних матеріалів у цьому осередкові. Після смерті легендарного українського видавця багатолітнього одинокого і потужного українського видавництва у Мюнхені «Дніпрова Хвиля» Олекси Вінтоняка його архівна колекція чомусь не потрапила в УВУ, а роззосередилася здебільшого в приватних руках.

Приклад забуття можна навести і з долею провідної газети західної української діаспори - «Української Думки». У листопаді 2016 року у Лондоні відбулася Міжнародна конференція з нагоди 70-річчя Союзу Українців у Великобританії (СУБ). Упродовж усіх цих років СУБ був засновником і видавцем цієї газети. Та вона перестала виходити в світ трохи менше ніж через рік після цієї конференції - у липні 2017 року. Також не оцифрована і не мала сайту. На сьогодні її історія недосліджена. В Інтернеті можна знайти куцу й до того ж неточну інформацію навіть про час їі заснування.

Джерельна база

Повної підшивки ні «Української Думки», ні її попередниць - «Нашого Кличу» та «Українського Кличу» в жодній книгозбірні України немає.

Стовідсткові комплекти річників «Української Думки» в належному стані зберігаються нині в Лондоні - у Бібліотеці-архіві ім. Тараса Шевченка Союзу Українців у Великій Британії. Саме із цими комплектами працював автор під час наукового стажування у Великій Британії. Принагідно були опрацьовані архівні матеріали Української Видавничої Спілки в Лондоні, Архіву Українського пресового бюро, власником якого $є$ нині Польський Інститут Лондона, а також фонди Британської Національної Бібліотеки (British Library).

Завдання статті

Завданнями цієї наукової розвідки є:

- зібрати зі шпальт часопису та редакційного архіву, систематизувати та увести до наукового обігу різноманітний фактологічний матеріал у конкретиці переду- 
мов постання, ствердження та розвою головної газети післявоєнної української еміграції у Великій Британії «Українська Думка»;

- проаналізувати редакційну політику часопису в реалізації спроб самоідентифікації українців-емігрантів та виживання в чужомовному оточенні.

Виклад основного матеріалу

Спеціальні дослідження історії цієї газети досі не проводилися. Маємо принагідні згадки про неї. Деякі з них потребують уточнення. Два приклади. В Інтернет-Енциклопедії «Українці у Сполученому Королівстві», яка створюється силами лондонських українців, називається неправильна дата заснування цієї газети - 1945 замість 1947 рік (Кравець, б. р.).

Ця ж помилка повторюється і у Вікіпедії («Українська Думка», 2018).

Куці принагідні, до того ж суперечливі, замітки про цей поважний друкований орган із 70-літньою історією, актуалізують першопрочитання підшивки цієї газети в контексті першої спроби написання іiї історії.

\section{Вибір між поміркованим і радикальним напрямками}

Згальновідомим $є$ факт, що українська еміграція на британських островах $\epsilon$ одна 3 наймолодших міграційних формацій у Західній Європі. Її основу склали десятки тисяч здебільше молодих українців, які вимушено залишили Батьківщину в час і після завершення Другої світової війни.

Організована поява їх на теренах Великої Британії проглядається за трьома головними потоками:

1. Вояки українського походження з канадських та польських військових формувань, які воювали проти фашистської Німеччини в складі країн антигітлерівської коаліції.

2. Колишні вояки дивізії СС «Галичина», перейменованої 3 жовтня 1944 року на Першу дивізію Української Національної Армії (УНА), яких рішенням британського уряду було прийнято на постійне мешкання з таборів військовополонених «Ріміні» та «Белярія».

3. Українські скитальники з так званих таборів Ді-Пі, що десятками тисяч розміщувалися в американській і англійській зонах звільнення країн Західної Європи від фашистського режиму.

В усіх трьох потоках емігрантів домінував політичний вибір: це були національно свідомі молоді українці, переважно чоловіки, які прямо чи опосередковано чинили опір насаджуваним Москвою тоталітарним методам організації суспільного життя на українських теренах. Вони вірили, що на еміграції їм не доведеться довго затриматися, що час розв'язання задавненого українського питання $з$ допомогою світової спільноти не забариться.

Звідси стають зрозумілими перипетії, пов'язані із двома підходами представників організованої української громади, що формувалася на теренах Великої Британії, до розв'язання цього найголовнішого питання.

Прихильники першого підходу продовжували розбудовувати на місцях так звані клітини своєї громадської організації - СУБ (Союз українців у Великій Британії). Поступово вони перебрали під свій контроль редакцію газети «Український Клич».

Як це сталося? 
Перше число цієї газети побачило світ 18 листопада 1945. Це був друкований на різографі бюлетень. У своєрідній передовій «До наших читачів» наголошувалося, що видання призначене для всіх українців у країні нового поселення і що воно має стати спільною трибуною для висловлювання різних думок.

На початку засновники «Українського Кличу» (а це були активісти Союзу Українських вояків у Польських Збройних Силах) прагнули не примикати ні до якого партійництва і не виражати думку лише вузької частини суспільної думки. Це простежувалося упродовж усього періоду існування цього друкованого первістка українців на британських островах. Газета проіснувала трохи більше року до 12 січня 1947 року. За цей час вийшло 12 чисел.

9 лютого 1947 року до всіх передплатників «Нашого Кличу» прийшла газета 3 новою назвою - «Українська Думка». Про мотивацію зміни назви оновлена редакція пояснила у другому числі так: «Управа СУБ змінила попередню назву «Наш Клич» на «Українська Думка». СУБ керувався в цьому тим, що орган СУБ, як одинокий під цю пору український часопис на цих землях, повинен мати прикметник «український» («Від редакції», 1947).

Таким чином, новопостала організація СУБ перебрала керівництво «Нашого Кличу» ще на етапі його статусу інформаційного бюлетеня. Змінивши назву газети, засновник «обнулив» і нумерацію нового видання. Звідси випливає, що починати літочислення «Української Дуки» від часу заснування газети «Український Клич» (18 листопада 1945 року) не коректно. СУБ первинно не засновував цієї газети, а лиш із часом набув їі.

Прихильники другого підходу формування засад громадської діяльності організованого українства в країні нового поселення були перейняті гострою потребою пропагування ідей українського національно-визвольного руху та українського організованого націоналізму. У них була сильніша надія швидкого повернення в небільшовицьку Україну. Саме ця група засновує в серпні 1947 року газету «Український Клич», а згодом і власне видавництво під назвою «Українська Видавнича Спілка».

\section{Спроби виражати думки всіх}

Набувши в дещо недемократичний спосіб газету із сталим колом читачів та репутацією цікавого періодичного видання, управа СУБ усе ж робить активні кроки щодо позиціонування «Української Думки» як трибуни для всього українського загалу.

Це стає зрозумілим на третьому місяці ㄲi випуску. Після придбання власної друкарні з'явився шанс перетворити скромний за формою та змістом бюлетень СУБ, що виходив двічі на місяць, на часопис усіх українців у Великій Британії. Для цього потрібно було виконати два нагальні питання: забезпечити випуск щотижнево, а не двічі на місяць, як було доти, й урізноманітнити проблематику публікацій.

На думку редакції, газета має стати: трибуною для всіх читачів; задовольняти потреби та вимоги кожного; посередником виміни думок загалу. Так сформувалося звернення до читачів, у якому виголошувалася програма-мінімум: «Ми ще раз закликаємо всіх українців, хто тільки спосібний висловити свою думку на папері - до співпраці. Що хоче отримати від читачів редакція? Дописи про життя українців, головно на островах; статті та власні твори читачів (дискусійні, спогади, оповідання й 
поезії). Справи, які цікавлять поодинокі особи, можуть бути цікавими для багатьох читачів» («Від видавництва», 1947).

Намір зробити випуск газети щотижневим вдалося втілити наприкінці вересня того ж року. 3 цієї нагоди редакція вміщує чергове звернення до читачів, у якому окреслені деякі уточнення щодо своєї редакційної політики.

Значення переходу на тижневик, наголошується в цьому зверненні, не в зовнішньому оформленні, а в національно-громадській місії. Суть цієї місії - це еміграційне послання українського друкованого слова на чужині, яке має будити «живих i мертвих, i ненароджених» ізгоїв українського чорнозему, що під чужими зорями кращої шукають долі. Це послання животворної національної державницької ідеї, яка в своїх початках передається в друк чи живому слові, а здійснюється в чині. Отож, і служіння ідеї нашого, розпорошеного хуртовиною війни, збірного національного життя, служіння усім починам, почерез які ця ідея здійснюється - оце й основне завдання вільної української преси стає водночас і нашим корінним завданням» («Наш тижневик», 1947).

Із цього звернення чітко проглядаються два головні напрямки діяльності редколегії:

1. Прагнення стати трибуною тих загальноукраїнських справ, за вирішення яких змагається вся українська діаспора. («Стоячи осторонь усякого партійництва і політичної загумінковости, ми хочемо стати виразником тих основних ідей, які єдино спільні кожній свідомій українській людині»).

2. Цільність цих проблем пов'язувати з широким руслом загальносвітових течій загальноєвропейських цінностей і християнських чеснот.

Ще одну спробу виражати думки всієї спільноти реакція газети робить на початку жовтня, закликаючи загал примножувати ряди передплатників та активніше присилати замітки 3 місць. «Ріст часопису в глибину й ширину тепер узалежнені від підтримки суспільства. Поможете масі собі зробити відраднішим етап вашого перебування на чужині, бо отримаєте в руки розраду в виді друкованого слова», йдеться в черговому зверненні до читачів («До наших читачів», 1947).

Частота схожих звернень до читачів, методична повторюваність закликів гуртуватися довкола газети вказує на те, що початковий етап становлення газети був непростим. Особливо він ускладнився з появою в серпні 1947 року першого числа нової газети «Український Клич».

Виглядає так, що перша реакція на цю подію управи СУБу, як єдиної на той час громадської організації українців у цій країні, не була адекватною. Замість спокійно сприйняти факт появи нової газети земляків та зосередитися на вдосконаленні змісту своєї, управа цієї організації активно пішла в наступ на конкурентів. До того ж, у хід пішли прийоми, які не були властивими демократичному суспільству, в якому опинилися емігранти з України.

Ось переконливі цитати, які підтверджують цю думку. Більше того, засвічують неприховану нетерпимість до іншого підходу в розв'язанні нагальних питань громадського життя, огульність критики, бажання надати суперечці публічного характеру:

«Ми тут бідні і матеріальні засоби наших людей замалі, щоб дозволити удержування двох часописів. Тим часом знайшовся «гурток українців у Лондоні», як про 
себе пишуть видавці «Українського Кличу», який узнав, що нині настала пора творити новий часопис і закликав усіх «гуртуватися довкола «Українського Кличу»...

«Хто $є$ цей гурт українців - невідомо... Чому треба гуртуватися довкола цього часопису - теж невідомо, бо гуртуються люди в організаціях».

«Своїм змістом УК не дав нічого нового, про що вже наш часопис раніше писав»)...

«Отаманія була і є прокляттям українського суспільного життя. Виявом цієї отаманії і $є$ поява «Українського Кличу». Й тому ми не можемо привітати появу цієї газети в українській мові на наших теренах, як це нормально належало зробити» («Нездорові прояви», 1947).

Правильно вказавши на одну із задавнених хвороб українського суспільного руху - отаманію, - автори цього невиправдано гострого матеріалу самі уподібнилися до тих отаманів, які вважали, що тільки їхні думки та дії є цілковито правильними, інших не може бути. Натомість, які відомо, здорова конкуренція - завжди творить сприятливий грунт для результативнішої праці.

Після того, як вляглися пристрасті, викликані появою нової газети, керівництво СУБу робить чергову спробу реорганізації свого друкованого органу.

Спонукане це було двома причинами.

Перша: організованим переїздом до Англії третьої, значної за кількістю, групи українців з італійського табору Ріміні. Важливо було оперативно залучити цю групу до громадських справ СУБу.

Друга: нагальною потребою тісної координації дій двох громадських організацій: Центрального Українського Допомогового Бюро в Лондоні (ЦУДБ) і Союзу Українців у Великій Британії (СУБ). Таким чином, газету «Українська Думка» вирішено було зробити органом цих двох організацій.

У зверненні до читачів стосовно цього повідомлялося таке: «Віримо, що почин видавати один український тижневик силами двох організацій наші читачі сприймуть». («До наших читачів», 1947, 15 вересня). Тоді ж ці дві організації стали співзасновниками видавництва під назвою «Українське видавництво і книгарня».

Процес увиразнення чіткої позиції «Української Дуки», таким чином, все ще тривав. На початку 1949 року в газеті публікується ще одне звернення до читачів під заголовком «Хочемо мати часопис більший, дешевший і частіше». У ній ідеться про те, що, попри неспростовні заслуги, газета поки не сповнила основних своїх завдань. Читачі вимагали більшого обсягу, частішого виходу в світ, дешевшої ціни передплати. Але досягнути цього можна було лише помітним збільшенням накладу.

Востанне корекцію редакційної політики на початковому етапі становлення було зроблено у травні 1949 року. На ту пору громадське життя українців переживало конфлікти, одна за одною виникали кризи в міжгрупових стосунках. I за цих умов потрібно було чіткіше окреслити завдання часопису. Цим викликана поява 7 травня редакційної статті «Слово до наших читачів: Кілька завваг про позиції і завдання «Української Думки». Ось витяг з неї:

«В українському громадському житті у Великій Британії склалася ситуація, що вважаємо потрібним виразніше окреслити завдання часопису.

Для чого це потрібно? Читачі мають знати, на яких позиціях стоїмо і які маємо завдання. Наша попередньо озвучена позиція, що ми - понадпартійний орган 
української загальнонаціональної думки, не змінюється, але потребує уточнення» («Кілька завваг про позиції і завдання», 1949).

Звернення закінчувалося палким закликом до читачів разом подолати кризу у міжособистісних та міжгрупових стосунках, показати чужинцям уміння й бажання українців жити за демократичними принципами.

\section{Криза економіки вдаряє по газетній справі}

Період стабільного розвитку газетної справи лондонських українців тривав недовго. Нові випробування, цього разу економічного характеру, загострилися від початку 50-х років.

На той час уряд Великобританії, бажаючи дати раду галопуючій інфляції (ціни почали зростати, життя здорожувалося), прийняв рішення підняти зарплату в усіх галузях виробництва товарів. Відповідно, отримали таке підвищення і друкарі, виробники паперу, поштові службовці. Як наслідок - помітно збільшилася ціна паперу, поштових послуг.

Це, своєю чергою, призводило до неминучого підвищення собівартості випуску газети. Відповідно, мала би зрости передплата на «Українську Думку».

На такий крок редакція не відважувалася. Адже тенденція до спаду накладу ставала очевидною. За результатами передплати на 1951 рік, наклад газети зменшувався на 170 примірників. Це значить, наголошувалося в зверненні до читачів, що «газета занепадає» («Шановні читачі і передплатники», 1951).

На те, окрім економічних, були дві причини внутрішнього характеру.

Перша - об'єктивна: 3 кінця 40-х років, зважаючи на економічну кризу, значна частина українських емігрантів, у пошуках кращої долі, відпливає за океан - в Америку та Австралію. Процес той був незворотнім.

Друга причина - суб’єктивна: значний відсоток українців все ще не був привчений читати газету. Отож, резерв збільшення кількості передплатників, а, отже, зменшення собівартості видання й уникнення підвищення суми переплати, виглядав чи не єдиним, який варто було максимально використати.

Цим пояснюється мало не благальний характер першошпальтового заклику: «Одинока на терені Великої Британії газета мусить бути втримана і поліпшена». Редакція твердо пообіцяла постійним передплатникам за невелику доплату та безплатно дарувати 3 наступного року свої нові книжкові видання (для цього й створено було своє видавництво). Йшлося також про намір поліпшити якість публікацій та розширити їхню тематику.

Окрім закликів, редакція, чи не вперше, впритул взялася у цім питанні за справи конкретні. Так поступово визрівала акція «За 500 нових передплатників». Починали з друкування передплатних бланків.

Типову форму бланків було опубліковано прямо на сторінці газети від 5 червня 1952 року. Таке незвичне для читачів починання супроводилося роз'ясненням: «Ціну газети підвищувати не бажаємо, бо це буде тягарем для читачів. Залишається лише одна дорога - збільшення числа передплатників (надходження з передплат покриє нам видатки на папір, друк та поштові оплати). Тому звертаємося до наших передплатників, прихильників, читачів, усіх, кому добро нашої газети лежить на серці з гарячим проханням допомогти газеті, приєднуючи принайменше по одному передплатникові... Не можемо допустити, щоб одинокий український тижневик тут, 
на терені Великої Британії, перестав виходити. Віримо, що загал допоможе» («До наших передплатників, читачів», 1952).

На підтримку такого починання до редакції надійшло кілька прихильних листів. Один із них надрукований у числі від 7 серпня 1952 р і мав назву «Дві категорії читачів газет» автора А. Андрука. Ось його зміст:

«Дозвольте «вдарити» по сумлінні тих людей, які, будучи українцями, цікавляться громадським і політичним життям нашої еміграції й люблять читати українську пресу, але однак, жалують грошей для передплати.

Маю на увазі дві категорії людей:

1. Ti, що мешкають зі своїми друзями в бараках чи спільних домах і користуються примірником, який хтось один передплатив.

2. Ti, які користуються часописами, які знаходяться в світлицях чи бібліотеках, і живуть у містах» (Андрук, 1952).

На початок березня 1953 року редакція підбила перші підсумки акції «За 500 нових передплатників» й опублікувала список активістів, хто, використовуючи опубліковані чисті бланки, залучив більше нових читачів. Список чималий. Варто навести 3 нього, для історії, перші кілька рядків: Гаргай-Гойда з Брадфорду - 20, I. Мисик з Едінбургу - 10, П. Дяків з Вулвергамптон - 10, I. Гундер з Болтону - 10, Й. Гузан з Актону - 5. Далі - чималий перелік тих, хто залучив від п'яти до двох нових передплатників («Акція «За 500 нових передплатників», 1953).

Акція тривала і в наступні місяці. Її результат дієвий: від неминучого банкрутства газету таки вдалося врятувати. Найскладніші 1951-1953 роки внаслідок надзусиль наклад газети вдалося не лише втримати, а й дещо наростити: якщо 1951 року він становив 3400 примірників, то в 1953-му - 3686. Втім, досягнути рівня найвищого тиражного благополуччя - близько 5000 примірників (1948 рік) «Українська Думка» вже ніколи не могла.

\section{Читачі ініціюють зміни}

Постійний пошук додаткових передплатників спонукав засновників у чергове переглянути редакційну політику. До цього також спонукали листи читачів. Так 3'явився на сторінках газети своєрідний дискусійний клуб під рубрикою «Якою має бути «Українська Думка».

Дискусію започаткував Василь Томків, лист якого був опублікований у новорічному числі 1954 року. Поряд із слушною критикою в листі містилося немало пропозицій (Томків, 1954).

3 критики:

- навіщо українцям у Британії читати повідомлення з радянської України, що там копають буряки?

- навіщо подавати застарілі міжнародні події, про які ми читаємо тижнем-двома раніше зі сторінок англомовних часописів?

3 пропозииій:

- вміщувати більше літературних творів місцевих авторів; більше гумору з українським перцем; доцільний куток розваг;

- не вистачає ребусів, загадок, хрестівок (так - про кросворди. - М. Т.).

Щоб ще більше заохотити читачів, автор пропонував запровадити конкурси, переможцям яких слід вручати призи. 
У сьогоднішнього читача цієї замітки неминуче виникає відчуття, що цей дописувач горів бажанням перетворити єдину на теренах Великої Британії загальноукраїнську газету на суто розважальну зі змістовими акцентами, які властиві більше для так званої жовтої преси.

Втім, були й інші думки читачів. Скажімо, I. Миро (число 3 за 1954 рік), опонуючи попередньому дописувачу, вважав за потрібне публікувати матеріали про ситуацію в радянській Україні. Однак він був проти, щоб редакція надавала перевагу вісткам, які показують тамтешнє життя лише в чорних тонах. Мовляв, в Україні скоро не стане українців, бо вони перестають говорити українською мовою. Дописувач наводить свіжий приклад із англійської преси, де йшлося детально про поїздку в Україну колишнього міністра США, яка родом з Люксембурга, Перл Мести. Вона сказала: «Найбільшою образою для українців було моє запитання - чи ви росіяни? Люди реагували на це, мов їх ударили по обличчю. Вони рішуче заперечували мені: ми не руські, ми - українці!». (Миро, 1954). Для посилення своїх аргументів I. Миро висловлює таке переконання: «Отож, так воно там не $є$ ! Українське слово не вдалося знищити Валуєву, не вдається й тепер його наслідникам. Україна не піддається насильству» (Миро, 1954).

3 огляду на перебіг дискусії та низку посутніх пропозицій із рясної читацької пошти, редакція вирішила ще раз оприлюднити своє баченням призначення української газети для вигнанців з рідної землі. Вийшов своєрідний декалог намірів українських журналістів на чужині. У своїй практичній роботі редакція ставила завдання залучити до співпраці здібних молодих людей, маючи на увазі виховувати 3 них нові кадри української журналістики і літератури на чужині («До дискусії на тему «Якою має бути УД», 1954).

25 жовтня 1956 року вийшло в світ 500-те число «Української Думки».

Редакція газета вирішила привернути увагу української спільноти до цього своєрідного ювілею скромною передовою статтею. Між її рядками упізнається рука вправного журналіста, який свідомо уникає зайвої патетики, хвалькуватості, але пам'ятає про високу місію, яка випала на долю не такому вже й великому гурту творців цієї газети. Вдало обіграна тут глибинна назва газети, яка багато до чого зобов'язуе.

«Відзначаючи ювілей газети, треба віддати належне тим, хто «впали» на думку дати газеті таку гарну і одночасно таку зобов'язуючу назву. Можна бути чистокровним українцем, але думати по-московськи, по-польськи, по-німецьки чи по-англійськи... I, на жаль, багато з нас так і роблять. А коли зважити, що думка попереджує чини, то можна уявити, до якої небезпеки ми могли б дійти, якщо б у нас не було української думки. В різні періоди і різною мірою газета «Українська Думка» намагалася оправдати свою назву українським змістом. За останні 10 років УД сповняла з честю своє завдання не лише як звичайний зв'язковий СУБу, а й пропагатором правдивої інформації і правдивих українських думок. УД завжди нестиме на своїх сторінках українську думку» («500 чисел «Української Думки», 1956).

\section{Редактори та співробітники}

Редакторський корпус «Української Думки» найменш вивчений. Прізвища тих, хто стояв біля керма газети, не завжди зазначалися на вихідних відомостях. Отож, дані про них найвірогідніше шукати в річних звітах та протоколах Управи СУБу, 
оригінали яких зберігаються нині в Бібліотеці-архіві ім. Шевченка цієї організації в Лондоні.

Аналіз цих звітів дає змогу зробити два однозначні висновки.

1. Оскільки редакція «Української Думки» підпорядковувалася централі СУБу, призначення і звільнення редакторів та членів редколегії відбувалися за ухвалою Управи на подання Голови.

2. Упродовж перших десяти літ існування керівництво редакції (а це редактор і адміністратор) змінювалося... десять разів.

Звісно, що така часта заміна головного керманича редакційного колективу не могла не позначатися на якості роботи і випуску газети.

Короткі репліки чи примітки в протоколах засідання СУБу щодо діяльності редакцій на початках її становлення наводять на думку, що між Управою СУБу та редакторами часто не було однозгідності у питаннях незалежної редакційної політики та політичної лінії СУБу. Незважаючи на часте оприлюднення тези про те, що «Українська Думка» - орган для усіх українців (це особливо помітно в численних зверненнях редакції до читачів), на практиці ж не кожен редактор був вільним у всебічному творчому самовираженні колективу. Це й було причиною низки частих відсторонень.

За даними протоколів Управи СУБу, у липні 1947 року з посади редактора був звільнений перший редактор і «Нашого Кличу», i «Української Думки» П. Пігічин. На початку 1948 року - М. Семчишин. У травні 1952 - М. Мироненко.

Усього кілька місяців (від жовтня 1953 до літа 1954 років) керував редакцією відомий у діаспорі дослідник, журналіст і письменник О. Воропай (Степовий). Той факт, що свої спогади «3 лондонського щоденника», щоденник утікача «В дорозі на Захід» та низку інших своїх творів Осип Воропай друкував не у видавництві СУБу, а в Українській Видавничій Спілці, свідчить про непрості його стосунки з президією організації-засновника, що й привело до звільнення.

Цікавий запис щодо взаємостосунків між редакцією і Управою СУБу міститься в «Комунікаті управи УД», опублікованій невдовзі після призначення О. Воропая редактором. Тут сказано: «Справу редагування УД обговорювала скликана в жовтні конференція, в якій взяли участь, крім членів Президії та ради СУБ з терену Лондону, деякі представники організацій, запрошені гості (проф. Щербаківський) та референти централі. Намічені заходи для збагачення змісту УД. Особливо звернена увага на зміст деяких дописів, які готувалися до друку невибагливо, в яких були надто різка критика, нецензурні слова, лайка, що викликало небажану реакцію читачів («Комунікат управи УД», 1953).

Найдовше на посаді редактора перебував I. Крушельницький - вісім років. Про нього у Звіті СУБ за 1960 рік сказано таке: «Вложив у справу багато труду. Пішов 3 посади за власним бажанням при кінці жовтня 1960 р. Багато допоміг новому редакторові, який тимчасово заступив його місце («Звіт СУБ за 1960 рік», 1961).

Повний список редакторів «Української Думки» за всю історію її існування виглядає так:

- Петро Пігічин (від листопада 1945, «Наш Клич», до жовтня 1946)

- Мирослав Семчишин (від серпня 1947 по березень 1949)

- Михайло Демкович-Добрянський (від квітня по листопад 1949) 
- Теодор Данилів (заодно секретар Ради СУБу) (від листопада 1949 по червень 1950)

- Микита Мироненко (з липня 1950 по березень 1952)

- І. Крушельницький - з березня 1952 по жовтень 1953

- Олекса Воропай - з жовтня 1953 по серпень 1954

- Іван Крушельницький - з червня 1954 по жовтень 1960

• Роман Борковський, від листопада 1960 по березень 1977 (співредактор М. Клименко).

- Святомир Фостун (від липня 1977 по липень 2004)

- Людмила Пекарська (від липня 2004 до грудня 2006)

- Володимир Олейко (від травня по липень 2007)

- Олекса Семенченко (від серпня 2007 по липень 2011)

- Людмила Пекарська (від липня 2011 по липень 2017)

Другою за вагомістю в редакції була посада адміністратора. До його обов'язків входила організація передплати, налагодження кореспондентської сітки та кольпортажу. Ці обов’язки виконували: М. Волинський, М. Добрянський, А. Тимкевич, В. Гоцький, В. Мащак (1964-1969).

Цінні дані про так звану корсітку - мережу власних кореспондентів в інших країнах, яку прагне мати кожна редакція газети чи журналу, якщо дбає про свою репутацію поза межами своєї країни. Зазвичай зарубіжними представниками періодичного органу ставали відомі громадські діячі й журналісти, які мешкали на місцях і пересилали до Лондона свої публікації. До їхніх обов’язків входило залучення передплатників у країні свого постійного перебування.

Перша мережа зарубіжних власкорів «Української Думки» була сформована в 1956 році й охоплювала Францію, Швейцарію, Німеччину та Канаду («Звіт СУБ за 1956 р.», 1957). Через два роки додалися свої власкори в Бельгії, Аргентині, Бразилії, Іспанії та СЗДА. Саме з цих країн періодично надсилалися для публікацій матеріали про життя українських емігрантів на чужині з особливим наголосом на діяльності організованих там українських громад.

Однак, за даними ж того Звіту, газеті так і не вдалося налагодити внутрішню корсітку, тобто на всіх теренах Великої Британії. Лише відділи СУБ надсилали інформацію з місць. Обмеженість коштів та відсутність у редакції спеціальних кореспондентів не давали змоги посилати штатних працівників у відрядження.

У 1969 році редакція мала 30 співробітників, в тому числі 20 - на терені Великої Британії, 10 - поза її межами.

\section{Про наклади, видатки і гонорари}

Наклади

Величина накладу того чи того періодичного видання має вагу в кількох вимірах. Передусім, це показник авторитетності, довіри читача. По-друге, це вагомий критерій впливу на громадську думку певної спільноти. Це також барометр фінансового стану редакції чи видавництва як підприємства.

3 означених вище складників проблематики доступною для дослідника може бути інформація лише про наклади. У більшості видань вона міститься у службовій частині. Однак традиційно в пресі української діаспори такі дані відсутні. Що ж до 
видатків (прибутків) та гонорарів, то та інформація є лише для службового користування і віднайти її можна лише в архівних теках редакцій.

Джерелом пошуку такої інформації стосовно газети «Українська Думка» послужили щорічні звіти про господарську діяльність її засновника - Союзу Українців у Великій Британії.

Зазвичай найкращим періодом для пресового і видавничого руху в української еміграції в європейських країнах після Другої світової війни є кінець 40-х - кінець 60-х років минулого століття. Це доба найбільшої громадської активності третьої хвилі еміграції, яка здебільшого була політичною. Його й беремо за основу аналізу.

Найбільш вдалим роком тиражного благополуччя «Української Думки» був 1948-й. Загальний наклад газети складав 4850 примірників. У наступні роки, через виїзд частини українців за океан, коло передплатників і покупців стало невпинно зменшуватися. Щороку, порівняно з попереднім, наклад скорочувався. Найбільший спад - понад 700 примірників - у 1949-му, найменший - близько 50-ти - в 1965 році. Саме в цьому році наклад сягнув найнижчої позначки за останні 20 літ і склав 2876 примірників. В інші роки він стабілізувався в межах 3000-3600 примірників.

3 огляду на існування розвинутої мережі закордонних представництв цікаво оглянути цифри відправки примірників цієї газети за роками. Починали в 1948 році із цифри 328. Найбільше передплатників поза межами Британії було в 1953 році 628. 3 наступного року почався невпинний спад: в 1954 - 534, 1956 - 451, 1957 - 277, $1969-201$.

Від 1957 року в міжнародному ардесарі розсилу газети з'являється додаткова графа «безплатні». Зазвичай це обмінні примірники з редакціями інших діаспорних видань, а також бібліотеки, наукові, просвітні та громадські інституції та організації українців у світі.

Таким чином, основний наклад «Української Думки» поширювався всередині країни. У звіті СУБу за 1969 рік вдалося віднайти дані про поширення накладу газети за цей рік у розрізі основних адміністративних районів Британії. Ці дані мають особливу цінність, адже дають змогу проаналізувати географію на кількість українських емігрантів на ту пору.

За цими даними, найбільша кількість передплатників УД мешкала в Лондоні 171. Далі так: Бредфорд - 85, Манчестер - 45, Лестер - 35, Ноттінгам - 35, Олдгам 35 , Рочдейл - 30, Ковентрі - 25, Болтон - 24, Кіхлей -22 , Галіфакс -20 , Пітсрборо 15 , Бері - 14, Волвергамптом - 14, Мансфілд - 13, Лутон - 11, Тисстед Камп - 10, Сканторп, Лідс - по 10, Аштон, Единбург - по 8, Діннінгтон - 6, Стокпорт, Чіддінфорд - по 5, Мірфілд, Свіндон, Фклікстон Камп - по 4, Рагбі Ньюкасл, Лій - по 3 примірники (Звіт СУБ за 1969, 1970).

\section{Видатки}

У всі проаналізовані роки випуску прибутки від передплати і оголошень не покривали витрат. Винятком був 1955 рік, коли підвищені ціни на передплату та за оголошення дали прибуток. Перевитрати покривалися за рахунок прибутку, що приносила книгарня при СУБі. Упродовж років саме книговидання у Великій Британії було прибутковою для українців справою. Робота редакційного персоналу оплачувалася з фонду СУБ, адміністратор газети - з фонду книгарні. 
Найбільші збитки від випуску газети припадають на 1948-1950, а також на 1961 роки: відповідно 736, 622, 615 і 1120 фунтів. Роки 1955-1958 були особливо сприятливими: реакційна праця виходила на плюс: 636 фунтів у 1955-му, 463 - у 1956 роках.

До стабільних складових прибутку (передплата, оголошення) додавалися традиційні для еміграції пожертви на пресовий фонд. Скажімо, в 1962 році за цією статтею в звіті значиться 1317 фунтів, роком раніше - 524. До організованих збірок пожертв на пресовий фонд реакція вдавалася періодично. Того року звернулася 3 окремим закликом до Українських клубів. Було зібрано 730 ф. і цим порятовано ситуацію від дефіциту. 1962 рік газета завершила із прибутком 48 ф.

\section{Гонорари}

Ця стаття витрат для кожної редакції українського періодичного друкованого органу на еміграції була в ті часи обов'язковою, незалежно від загального фінансового стану. Інша річ, що у співвідношенні до інших складників кошторису її питома вага була досить незначною. А в роки фінансової нестабільності саме цю статтю доводилося урізати найбільше.

Візьмемо для прикладу кошторис витрат за 1961 рік. Авторський гонорар тут зазначається в сумі 144 фунти.

Багато це чи мало?

Відповідь на це запитання може дати порівняння з іншими статтями витрат: оплата друку накладу та кліше - 4589 фунтів, поштові витрати - 1135, оплата праці редакційних працівників - 1512 фунтів. Якщо брати до уваги, що загальна сума витрат у тому році складає 7836 фунтів, то частка гонорару в цій сумі займає близько двох відсотків. Але й незначній частині цієї суми були раді інколи безробітні дописувачі.

Аналіз гонорарної статті за іншими роками засвідчує, що її величина через обмеженість редакційних ресурсів була ще меншою: в 1953 році - 98 фунтів, 1954 - 90, 1955 - 78 фунтів. Це, відповідно, гальмувало справу з покращання якості матеріалів.

\section{Головні теми}

На початку 1953 року питання про діяльність редакції «Української Думки» у чергове слухалося на засіданні правління СУБу. Безіменний «ревізор» зафіксував так для працівників редакції цікаву пораду: «Умисне варто дати огляд анатомії праці редакції, iї техніку, план та організацію: як працює редакція, як формуються газетні шпальти, показати невидиму читачеві муравлину роботу, яку роблять горстка одержимих людей, включаючи і коректорську роботу в друкарні» («У власній справі», 1953).

Редакція виконала таку пораду і вмістила незабаром цей огляд «анатомії своєї праці» в спільній публікації, що мала назву «У власній справі». Гадаю, піднята 3 небуття розповідь про особливості редакційної кухні в еміграції 40-50-х років минулого століття викличе непідробний інтерес не лише в творців сучасних газет.

Отож, як формувалися газетні шпальти, які теми піднімалися в публікаціях, у який спосіб вони формувалися, що і як виділялося за головне?

Почнемо з першої шпальти.

Редакція відстежувала головні події, що сталися за тиждень в країні та світі й намагалася викладати їх у рубриці «Коротко». Аргумент одного з дописувачів про те, що цього не потрібно робити, оскільки він має змогу довідатися про такі події 3 англійських газет, не був переконливим. Адже редакція краще знала середньоста- 
тичний рівень своїх передплатників. У більшості вони не знають англійської мови $і$ не могли за тими подіями встежити з чужомовних часописів. Таких, хто добре знав англійську, було небагато.

Вісті подаються без коментарів. Читачеві давалася можливість самому робить висновки. Коментуючи цю частину своєї роботи, редакція не без гумору зазначала: «Не аналізуємо занадто події, не даємо гороскопів, щоби не впасти у ворожбитство».

Всі інші публікації присвячувалися висвітленню головно проблем і подій українського життя в цілому, і громади зокрема.

Зазвичай на відкритті кожного числа вміщувалася вступна стаття (у Старому Краї її називали передовою, отож - на передовиці номера).

У ній порушувалися певні політичні або суспільно-політичні проблеми життя українців в еміграції. Підхід був чітко окреслений - загальноукраїнські, всенаціональні інтереси. Про багато справ, які піднімалися на шпальтах «Української Думки», ішлося в інших еміграційних виданнях. Низка проблем, які порушувалися в пресі, ставали поштовхом організаціям і установам до практичних дій.

Головне інформаційне навантаження мали публікації рубрик «Вісті з України» та «Українська хроніка».

«Bicmi з України» - це інформації про всі важливі події з українських земель, які мали для емігрантів інтерес і значення. Зазвичай це були витинанки з газет, що виходили в підрадянській частині України і які редакційні працівники ретельно студіювали.

Рубрика «Украӥнська хроніка» - відомості про життя, осяги, труднощі та недоліки життя на еміграції в країнах вільного світу. Побіч справ, що торкалися діяльності створених українцями громадських організацій на науково-просвітницьких інституцій, багато місця виділялося публікаціям персонального характеру. Їх давали тому, що це для читачів було єдине джерело інформації видатніших діячів та осіб, яких знали в краю, і які, опинившись на еміграції, продовжували свою посвяту громадським справам. (Приклади - відновлення діяльності львівської «Червоної Калини», переїзд Івана Тиктора до Канади, заснування й перші кроки діяльності Українського Вільного Університету, видання в Сарселі перших томів «Енциклопедії українознавства» тощо).

Цікава деталь: матеріали цієї рубрики охоплюють усі континенти, де опинилися українці: обидві Америки, Азія, Африка, Свропа. Щоб дати відомості звідусіль, працівники редакції мусили щотижня переглядати і студіювати до 50 українських часописів, які приходять 3 тих країв до редакції.

Праці авторів-науковиів. Редакція стояла на тому, щоб дати матеріал і актуальний, і вартісний передусім із пізнавального та виховного боку. УД охоче публікувала аналітичні статті та нариси таких активних дописувачів - професорів Щербківського, Державина, Курінного, історика В. Мацяка, інших відомих українських учених на еміграції.

Про значення цього сегменту публікацій у статті говориться так: «Ці праці стануть колись у великій пригоді для наших дослідників навіть тоді, коли вже повернемо на рідні землі. В час, коли наш видавничий ринок $є$ дуже обмеженим через нестачі фондів, сторінки наших газет частково можуть заповнити прогалину публікації праць наших учених. Цей факт свідчить, що наша газета буде вартісна ще по довгих 
роках після. Вона матиме стрес також і для дослідника історії нашої еміграції в західному світі» («У власній справі», 1953).

Статті власних кореспондентів на місиях із краӥн нового поселення украӥнців. Фактично це матеріали з перших рук. Вони цінні тим, що їхні автори жили й творили в гущі мас, добре знали життя своїх земляків, були небайдужими до їхніх добрих справ та намірів.

Матеріали про життя украӥнців у Великій Британії. Коли б зібрати докупи всі публікації цієї теми, вийде цікава хроніка, але послідовного ствердження українства на чужині наперекір труднощам і випробуванням.

Нотатки із англійської преси про українців. Про хід висвітлення цієї теми говориться так: «Публікації цієї рубрики свідчать, що ми своєю поведінкою і працею завойовуємо собі симпатії господарів. Водночас поміщуємо тут і матеріали про те і про тих, що компрометує нас. Це для застереження інших».

\section{Висновки}

Із трьох українських газет, які з'явилися на теренах Великої Британії після Другої світової війни («Наш Клич», «Український Клич» і «Українська Думка») саме «Українській Думці» випала місія головного й авторитетного друкованого органу, який найдовше проіснував у цій країні, - понад 70 років.

За непростих умов, що складалися, редакції вдалося знайти власне обличчя і посісти належне місце справжнього літописця і справжнього організатора життя однієї з чисельних українських громад на чужині.

Незважаючи на часту корекцію редакційної політики «Української Думки», засадничим чинником її виживання було дотримання і засновником, і редакційним колективом принципової позиції: українська газета на чужині не є прибутковим підприємством, вона $є$ важливою націєтворчою і націєцентричною інституцією для всієї громади, і її треба будь що зберегти.

\section{СПИСОК ЛІТЕРАТУРИ}

1. Акція «За 500 нових передплатників». (1953, 12 березня). Українська Думка.

2. Андрук, А. (1952, 5 серпня). Дві категорії читачів газет. Українська Думка.

3. Від видавництва. (1947. 16 травня). Украӥнська Думка.

4. Від редакції. (1947, 22 лютого). Українська Думка, Ч 2.

5. До дискусії на тему «Якою має бути УД» (1954, 8 січня). Від редакції. Українська Думка, Ч. 1-2.

6. До наших передплатників, читачів, прихильників та до всього українського громадянства. (1952, 5 червня). Українська Думка.

7. До наших читачів (1947, 15 вересня). Українська Думка.

8. До наших читачів. (1947, 9 жовтня). Українська Думка.

9. Звіт СУБ за 1956 рік. (1957). Папка «Щорічні звіти СУБ». Архів Бібліотеки імені Шевченка Союзу Українців у Великій Британії (СУБ).

10. Звіт СУБ за 1960 рік. (1961). Папка «Щорічні звіти СУБ». Архів Бібліотеки імені Шевченка Союзу Українців у Великій Британії (СУБ).

11. Звіт СУБ за 1969 рік. (1970). Папка «Щорічні звіти СУБ». Архів Бібліотеки імені Шевченка Союзу Українців у Великій Британії (СУБ). 
12. Кілька завваг про позиції і завдання «Української Думки». (1949. 7 травня). Українська Думка.

13. Комунікат управи УД. (1953. 22 жовтня). Українська Думка.

14. Кравець, Р. (б. р.). «Українська Думка». Взято з http://www.ukrainiansintheuk.info/ ukr/04/ukrdumka-u.htm

15. Миро, І. (1954). Хвальна редакціє УД. Українська Думка, Ч. 3.

16. Наш тижневик. (1947, 26 вересня). Українська Думка.

17. Нездорові прояви. (1947, 3 серпня). Українська Думка.

18. 500 чисел «Української Думки». (1956, 25 жовтня). Українська Думка.

19. Томків, В. (1954, 8 січня). До хвальної редакції та адміністрації Уд. Українська Думка, Ч. 1-2.

20. У власній справі. (1953, 19 лютого). Українська Думка.

21. Українська Думка (Велика Британія). (2018). Взято з https:/qrgo.page.link/YGYLr

22. Шановні читачі і передплатники. (1951, 18 жовтня). Українська Думка.

\section{REFERENCES}

1. Aktsiia «Za 500 novykh peredplatnykiv» [Aktsiia «For 500 new subscribers»]. (1953, March 12). Ukrainska Dumka [in Ukrainian].

2. Andruk, A. (1952, August 5). Dvi katehorii chytachiv hazet [Two categories of newspaper readers]. Ukrainska Dumka [in Ukrainian].

3. Do dyskusii na temu «Iakoiu maie buty UD» [To the discussion on «What should be the UD»]. (1954, January 8). Vid redaktsii [From the editorial board]. Ukrainska Dumka, Pt. 1-2 [in Ukrainian].

4. Do nashykh chytachiv [To our readers]. (1947, October 9). Ukrainska Dumka [in Ukrainian].

5. Do nashykh chytachiv [To our readers]. (1947, September 15). Ukrainska Dumka [in Ukrainian].

6. Do nashykh peredplatnykiv, chytachiv, prykhylnykiv ta do vsoho ukrainskoho hromadianstva [To our subscribers, readers, supporters and all Ukrainian citizenship]. (1952, June 5). Ukrainska Dumka [in Ukrainian].

7. Kilka zavvah pro pozytsii i zavdannia «Ukrainskoi Dumky» [A few notes on the positions and tasks of Ukrainian Thought]. (1949, May 7). Ukrainska Dumka [in Ukrainian].

8. Komunikat upravy UD [UD Management Communication]. (1953, October 22). Ukrainska Dumka [in Ukrainian].

9. Kravets, R. (n.d.). «Ukrainska Dumka» [Ukrainian Thought]. Retrieved from http:// www.ukrainiansintheuk.info/ukr/04/ukrdumka-u.htm [in Ukrainian].

10. Myro, I. (1954). Khvalna redaktsiie UD [Honorable editorial staff of the UD]. Ukrainska Dumka, Pt. 3 [in Ukrainian].

11. Nash tyzhnevyk [Our weekly]. (1947, September 26). Ukrainska Dumka [in Ukrainian].

12. Nezdorovi proiavy [Unhealthy manifestations]. (1947, August 3). Ukrainska Dumka [in Ukrainian].

13. 500 chysel «Ukrainskoi Dumky» [500 numbers of Ukrainian Thought]. (1956, October 25). Ukrainska Dumka [in Ukrainian].

14. Shanovni chytachi i peredplatnyky [Dear readers and subscribers]. (1951, October 18). Ukrainska Dumka [in Ukrainian]. 
15. Tomkiv, V. (1954, January 8). Do khvalnoi redaktsii ta administratsii UD [To the laudatory editorial board and administration of the UD]. Ukrainska Dumka, Pt. 1-2 [in Ukrainian].

16. U vlasnii spravi [In my own business]. (1953, February 19). Ukrainska Dumka [in Ukrainian].

17. Ukrainska Dumka (Velyka Brytaniia) [Ukrainian Opinion (United Kingdom)]. (2018). Retrieved from https://qrgo.page.link/YGYLr [in Ukrainian].

18. Vid redaktsii [From the editorial board]. (1947, February 22). Ukrainska Dumka, Pt. 2 [in Ukrainian].

19. Vid vydavnytstva [From the publishing house]. (1947, May 16). Ukrainska Dumka [in Ukrainian].

20.Zvit SUB za 1956 rik [SUB Report for 1956]. (1957). Papka «Shchorichni zvity SUB» [Folder Annual Sub Reports]. Arkhiv Biblioteky imeni Shevchenka Soiuzu Ukraintsiv u Velykii Brytanii (SUB) [in Ukrainian].

21. Zvit SUB za 1960 rik [SUB Report for 1960]. (1961). Papka «Shchorichni zvity SUB» [Folder Annual Sub Reports]. Arkhiv Biblioteky imeni Shevchenka Soiuzu Ukraintsiv u Velykii Brytanii (SUB) [in Ukrainian].

22.Zvit SUB za 1969 rik [SUB Report for 1969]. (1970). Papka «Shchorichni zvity SUB» [Folder Annual Sub Reports]. Arkhiv Biblioteky imeni Shevchenka Soiuzu Ukraintsiv u Velykii Brytanii (SUB) [in Ukrainian]. 


\title{
THE LONDON NEWSPAPER UKRAINSKA DUMKA (UKRAINIAN THOUGHT) (1947-2017): FORMATION, EDITORIAL POLICY, ATTEMPTS AT SELF-IDENTIFICATION AND SURVIVAL IN A FOREIGN-LANGUAGE ENVIRONMENT
}

\author{
Mykola Tymoshyk \\ Kyiv National University of Culture and Arts, \\ 36 Konovalets Street, 01133, Kyiv, Ukraine \\ e-mail:nkin@ukr.net \\ https://orcid.org/0000-0002-7011-3022
}

For the first time, one of the leading newspapers in the Western Ukrainian diaspora, London's Ukrainska Dumka (Ukrainian Thought), became the subject of research. Founded in 1947, it ceased to exist in 2017. There is no complete filing of this newspaper in any book collection of Ukraine, it has not been digitized yet, the editorial office did not have a site. For this reason, the author conducted a study of this newspaper in the library-archive of the Union of Ukrainians in Great Britain (UUB) in London.

The archival documents and materials of the Ukrainian Publishing Union in London and the British National Library (British Library) related to the activities of this editorial board were also the object of observation.

The peculiarities of journal formation and the specifics of the editorial policy are clarified. The analysis of the binder made it possible to clarify the date of foundation of the magazine, which in some online materials is incorrect.

The predecessor of Ukrainska Dumka (Ukrainian Thought), the Bulletin Nash Klych (Our Call), which the UUB took over later and made it its own organ, appeared on November 18, 1945. Ukrainska Dumka (Ukrainian Thought) was first published on February 9, 1947. It was this date that marked the first issue of the new newspaper. Therefore, it is inappropriate to consider the year of 1945 as the official year of Ukrainska Dumka (Ukrainian Thought)'s release.

Correction of the editorial policy of the magazine was as frequent as changes of editorsin-chief. This can be explained by the contradiction between the purpose of the editorial board to become a tribune of the entire Ukrainian element and the founder's attempts to comply with the statutory requirements of the organization.

Key words: Ukrainska Dumka (Ukrainian Thought) newspaper, Nash Klych (Our Call) newspaper, Ukrainian Diaspora, Union of Ukrainians in Great Britain, editorial policy. 